\title{
KOROSI ALUMINIUM DALAM LARUTAN ASAM SITRAT
}

\author{
Andreas Yoppy Aprianto Prasetya*, Isdiriayani Nurdin \\ Kelompok Keahlian Energi dan Sistem Pemrosesan Teknik Kimia \\ Program Studi Teknik Kimia, Fakultas Teknologi Industri \\ Institut Teknologi Bandung \\ Jalan Ganesha 10, Bandung 40132 \\ Email: yop_pras@hotmail.com
}

\begin{abstract}
Abstrak
Asam sitrat merupakan asam karboksilat yang banyak digunakan sebagai aditif pada industri minuman. Kaleng aluminium sering dipakai sebagai kemasan minuman karena sifatnya yang ringan, efisien ruang, dan biaya produksinya rendah. Kontak asam sitrat dengan kemasan berupa kaleng aluminium dapat menyebabkan reaksi korosi yang berujung kontaminasi produk korosi terhadap minuman. Penelitian ini bertujuan untuk menguji ketahanan aluminium terhadap korosivitas asam sitrat pada konsentrasi 1 , 2, dan $4 \%$-b, serta temperatur $40{ }^{\circ} \mathrm{C}, 50{ }^{\circ} \mathrm{C}$, dan $60^{\circ} \mathrm{C}$. Logam yang digunakan merupakan pelat aluminium dengan kemurnian 99,07\% dan luas permukaan $1 \mathrm{~cm}^{2}$. Penelitian mencakup pengukuran laju korosi aluminium dengan metoda Tafel dan prediksi mekanisme korosi aluminium dengan metoda voltametri siklik. Hasil penelitian yang dilakukan menunjukkan bahwa aluminium terkorosi dalam larutan asam sitrat menjadi $\mathrm{Al}^{3+}$ dengan satu tahap reaksi searah dan energi aktivasi sebesar 65,01 kJ/mol. Produknya bersifat tidak stabil, langsung membentuk garam aluminium amorf. Laju korosi aluminium meningkat seiring dengan meningkatnya konsentrasi asam sitrat dan temperatur, termasuk golongan korosi "dapat diabaikan" hingga "sedang".
\end{abstract}

Kata kunci: aluminium, konsentrasi asam sitrat, korosi, temperatur

\begin{abstract}
Citric acid is a carboxylic acid that is widely used as an additive in the beverage industry. Aluminum cans are often used as a beverage packaging due to its lightweight, space efficient, and low production costs. Contact between citric acid and the aluminum cans may cause corrosion reactions that lead contamination of beverages by corrosion products. This study aims to test the aluminum resistance against citric acid at the concentration of 1,2 , and $4 \%$ wt, and temperature of $40{ }^{\circ} \mathrm{C}, 50{ }^{\circ} \mathrm{C}$, and $60{ }^{\circ} \mathrm{C}$. The specimen used is a $1 \mathrm{~cm}^{2}$ aluminum plate with a purity of $99.07 \%$. The experiment consists of aluminum corrosion rate measurements using the Tafel method and aluminum corrosion mechanism prediction using cyclicvoltammetry method. The research results show that aluminum is corroded into $\mathrm{Al}^{3+}$ by citric acid solution in a one-stage reaction with activation energy of $65.01 \mathrm{~kJ} / \mathrm{mol}$. The corrosion products are not stable, it forms amorphous aluminum salts. The aluminum corrosion rate increases with rising citric acid concentration and temperature that can be classified in "negligible" to "medium" category.
\end{abstract}

Keywords: aluminum, citric acid concentration, corrosion, temperature

*korespondensi 


\section{Pendahuluan}

Pengemasan merupakan sistem yang terkoordinasi untuk menyiapkan barang menjadi siap untuk ditransportasikan, didistribusikan, disimpan, dijual, dan dipakai. Adanya wadah atau pembungkus dapat membantu mencegah atau mengurangi kerusakan, melindungi produk yang ada di dalamnya, melindungi dari bahaya pencemaran serta gangguan fisik (gesekan, benturan, getaran). Di samping itu, pengemasan berfungsi untuk menempatkan suatu hasil pengolahan atau produk industri agar mempunyai bentuk-bentuk yang memudahkan dalam penyimpanan, pengangkutan, dan distribusi (Brown dan James, 2003).

Kaleng logam pada umumnya dipakai untuk wadah minuman non-karbonasi, seperti: kopi, teh, minuman berenergi; dan juga untuk wadah minuman berkarbonasi, seperti minuman ringan dan bir. Kerusakan kaleng logam akibat interaksi antara logam bahan kaleng dengan minuman dapat berupa: perubahan warna pada bagian dalam kaleng, bahkan perkaratan atau terbentuknya lubang pada logam. Korosi pada kaleng biasanya terpicu oleh tingkat keasaman minuman, sisa oksigen-khususnya pada bagian atas kaleng (head space), yang sangat ditentukan oleh proses blanching, pengisian, dan exhausting-, komposisi bahan kaleng, temperatur dan lama penyimpanan, serta keberadaan zat-zat pemicu korosi, seperti salah satunya adalah asam sitrat (Robertson, 1993).

Pada dasarnya, aluminium dipakai karena ringan, harganya yang relatif terjangkau, dan ketahanan mekaniknya yang cukup baik sehingga dapat melindungi minuman dari tekanan luar (Winata dan Mardianto, 2010). Namun, data kuantitatif tentang ketahanan aluminium terhadap korosivitas asam sitrat belum banyak dipublikasikan.

Penelitian ini dimaksudkan untuk menguji ketahanan aluminium terhadap korosivitas asam sitrat di berbagai kondisi, terutama yang dapat mewakili kondisi minuman yang mengandung asam sitrat. Manfaat dari penelitian ini adalah diketahuinya tingkat ketahanan aluminium terhadap korosivitas asam sitrat sehingga dapat dijadikan landasan pengambilan keputusan mengenai kegunaan aluminium sebagai kemasan minuman yang mengandung asam sitrat.

\section{Metodologi \\ 2.1 Alat dan Bahan}

Bahan kimia yang digunakan pada penelitian ini adalah serbuk asam sitrat p.a., garam $\mathrm{KCl}$ p.a., Agarpac ${ }^{\circledR}$, aqua $\mathrm{dm}$, dan pelat aluminium $99,07 \%$ seluas $1 \mathrm{~cm}^{2}$. Permukaan pelat tersebut dihaluskan dengan kertas abrasif mulai grade 60 hingga 2000. Alat utama yang digunakan dalam percobaan ini adalah potensiostat dengan software Gamry Framework $^{\mathrm{TM}}$. Rangkaian alat untuk mengukur laju korosi ditampilkan pada Gambar 1. Polarization cell dan reference cell terbuat dari gelas berdiameter $\pm 15 \mathrm{~cm}$ dan tinggi $\pm 12 \mathrm{~cm}$. Jembatan garam $\mathrm{KCl}$ juga di dalam wadah gelas sepanjang $\pm 17 \mathrm{~cm}$ dan tinggi $\pm 10 \mathrm{~cm}$.

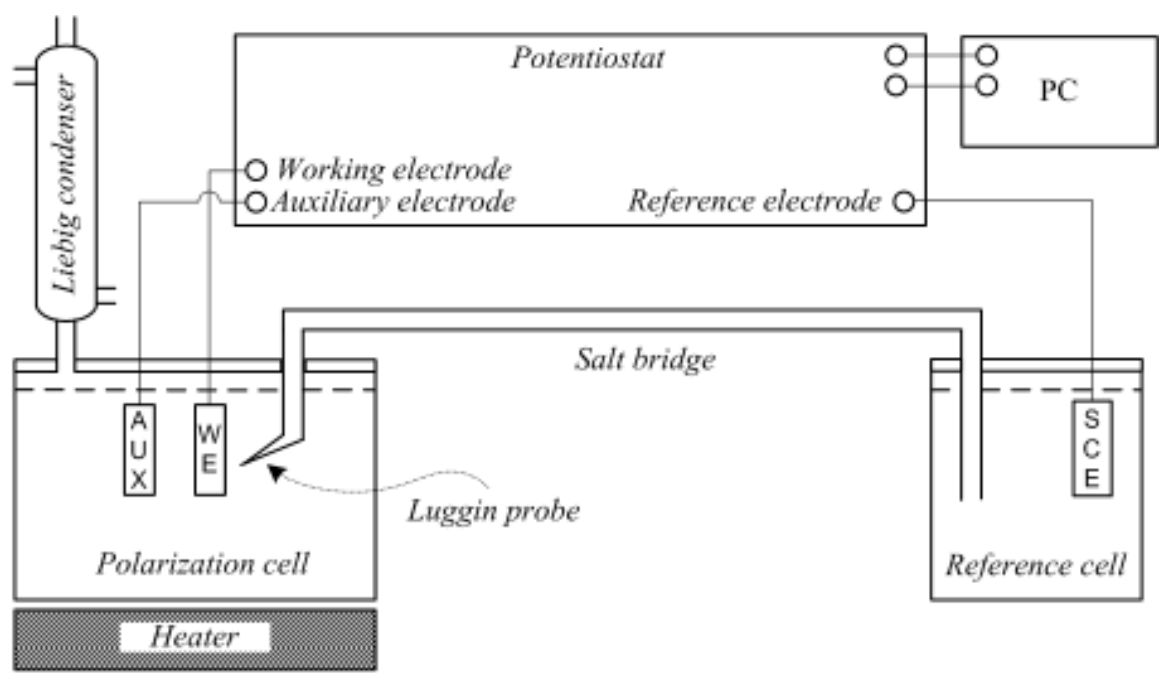

Gambar 1. Skema susunan alat polarisasi 


\subsection{Kondisi Percobaan}

Variasi konsentrasi larutan asam sitrat yang digunakan adalah 1, 2, dan 4\%-berat; sedangkan variasi temperatur yang dilakukan adalah 40,50 , dan $60^{\circ} \mathrm{C}$.

\subsection{Pengukuran Laju Korosi dan Prediksi Mekanisme Korosi}

Salah satu metoda pengukuran laju korosi adalah metoda ekstrapolasi Tafel menggunakan alat potensiostat. Potensial korosi dan rapat arus korosi merupakan koordinat titik potong bagian anodik dan katodik dari kurva polarisasi, yaitu kurva hubungan antara potensial dan rapat arus seperti ditunjukkan pada Gambar 2 (Jones, 1992).

Mekanisme reaksi korosi dapat diprediksi dengan menggunakan metode
Linear Potential Sweep Chronoamperometry, atau disebut juga Linear Sweep Voltametry (LSV). Variasi potensial secara linier dan bolak-balik terhadap waktu menghasilkan respon berupa perubahan arus terhadap waktu, yang digambarkan sebagai kurva hubungan arus terhadap potensial, seperti pada Gambar 3 (Bard dan Faulkner, 1983).

Voltamogram siklik memberikan informasi tentang reversibilitas reaksi, kestabilan produk korosi, dan jumlah tahap reaksi oksidasi maupun reduksi. Untuk sistem Nernstian dengan produk yang stabil, berlaku bahwa $i_{p a} / i_{p c} \approx 1$. Reaksi dikatakan reversibel jika $E_{p a}-E_{p c} \approx(0,118 / n)$ volt. Jumlah puncak anodik ataupun katodik menunjukkan jumlah tahap reaksi anodik ataupun katodik (Bard dan Faulkner, 1983).

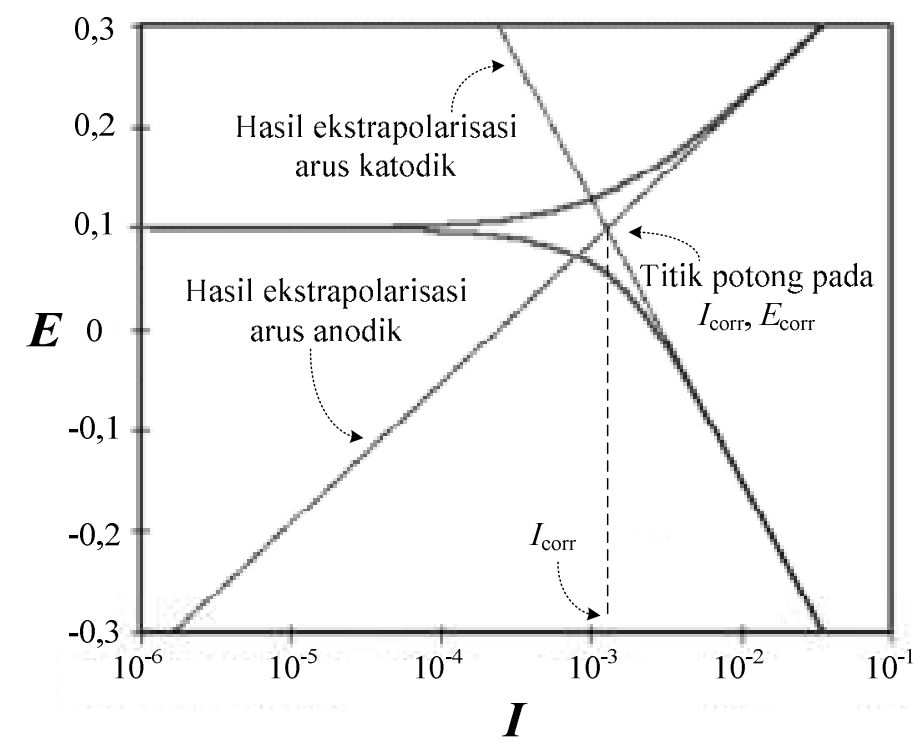

Gambar 2. Kurva polarisasi Tafel (Fontana, 1987)

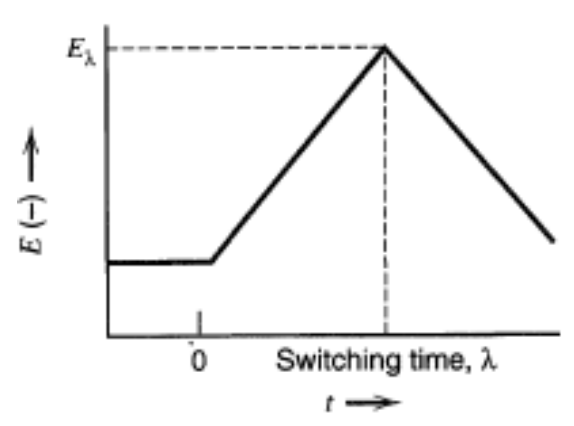

(a)

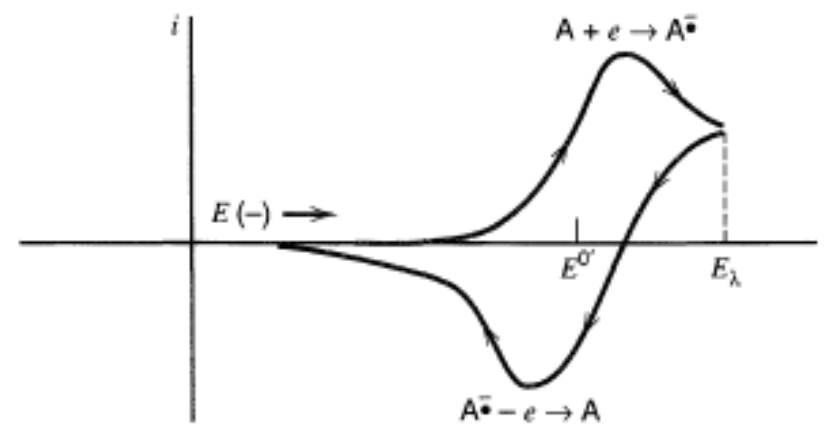

(b)

Gambar 3. (a) Grafik perubahan potensial siklik (b) hasil voltamogram siklik (Bard dan Faulkner, 1983) 


\section{Hasil dan Pembahasan}

Secara keseluruhan, penelitian ini meliputi pengukuran laju korosi dan pengamatan mekanisme korosi, yang merujuk pada penelitian Winata dan Mardianto (2010). Dalam rangkaian alat percobaan yang ditampilkan Gambar 3, pelat aluminium dipasang sebagai working electrode dan berfungsi menjadi anoda, kawat platina sebagai auxiliary electrode dan berfungsi menjadi katoda, serta saturated calomel electrode (SCE) sebagai reference electrode yang terhubung dengan sel uji melalui jembatan garam dan Luggin probe.

Saat proses polarisasi berlangsung, pelat aluminium mengalami korosi dengan reaksi:

$\mathrm{Al} \rightarrow \mathrm{Al}^{3+}+3 \mathrm{e}^{-}$

Pada permukaan kawat platina, muncul gelembung-gelembung gas $\mathrm{H}_{2}$ yang terbentuk dari reaksi:

$2 \mathrm{H}^{+}+2 \mathrm{e}^{-} \rightarrow \mathrm{H}_{2}$

Oleh karena itu, reaksi elektrokimia yang terjadi dalam sistem adalah:

$2 \mathrm{Al}+6 \mathrm{H}^{+} \rightarrow 2 \mathrm{Al}^{3+}+3 \mathrm{H}_{2}$

\subsection{Laju Korosi}

Laju korosi dan potensial korosi dalam penelitian diperoleh dari diagram Tafel dengan scan rate $1,67 \mathrm{mV} /$ detik dan sample period 5 detik. Salah satu diagram yang diperoleh diperlihatkan pada Gambar 4.

National Association of Corrosion Engineers (NACE, 1985) menyepakati bahwa korosi dapat diabaikan jika laju korosi bernilai kurang dari 0,0508 mm/tahun (2 mpy). Korosi "ringan" dikategorikan pada laju kurang dari 0,508 $\mathrm{mm} /$ tahun (20 mpy), "sedang" dalam rentang laju 0,508-1,270 mm/tahun (20-50 mpy), dan "parah" jika lajunya lebih besar dari 1,270 mm/tahun (50 mpy). Hasil pengukuran laju korosi aluminium dalam larutan asam sitrat disajikan pada Tabel 1 .

Tabel 1. Laju Korosi (mm/tahun) Aluminium dalam Larutan Asam Sitrat

\begin{tabular}{ccccc}
\hline & & \multicolumn{3}{c}{ Temperatur $\left({ }^{\circ} \mathbf{C}\right)$} \\
& & $\mathbf{4 0}$ & $\mathbf{5 0}$ & $\mathbf{6 0}$ \\
\hline \multirow{2}{*}{ Konsentrasi } & $\mathbf{1}$ & 0,004 & 0,112 & 0,241 \\
(\%-b) & $\mathbf{2}$ & 0,167 & 0,256 & 0,391 \\
& $\mathbf{4}$ & 0,540 & 0,675 & 0,817 \\
\hline
\end{tabular}

\subsubsection{Pengaruh Kenaikan Konsentrasi} Asam Sitrat dan Temperatur

Data-data pada Tabel 1 dapat dialurkan menjadi kurva hasil pengukuran laju korosi terhadap perubahan konsentrasi asam sitrat pada berbagai temperatur, seperti ditampilkan pada Gambar 5.

Gambar 5 memperlihatkan adanya kenaikan laju korosi seiring dengan kenaikan konsentrasi asam sitrat. Derajat keasaman $(\mathrm{pH})$ yang rendah membuat laju korosi meningkat. Hal tersebut disebabkan karena konsentrasi asam sitrat yang tinggi memiliki kandungan $\mathrm{H}^{+}$yang tinggi sehingga dapat meningkatkan jumlah partikel $\mathrm{H}^{+}$yang bereaksi dengan logam $\mathrm{Al}$ menurut Persamaan 5. Dengan kata lain, laju korosi menjadi lebih cepat.

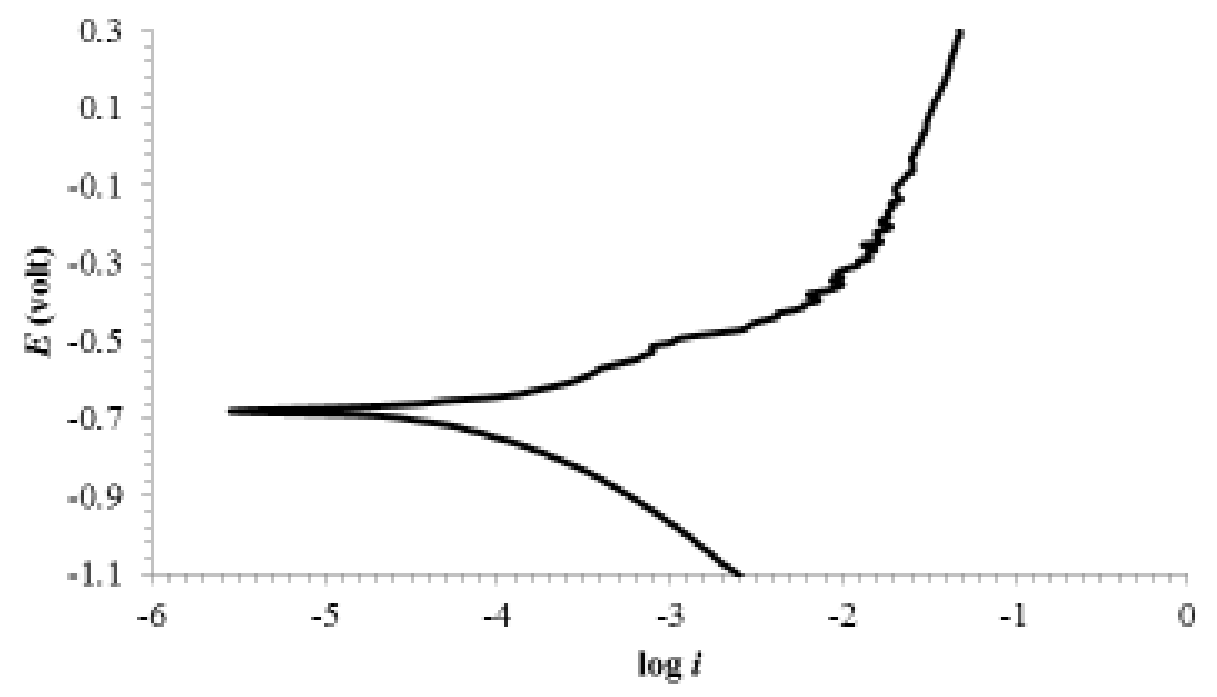

Gambar 4. Diagram Tafel korosi aluminium dalam larutan asam sitrat $2 \%$-b pada $40{ }^{\circ} \mathrm{C}$ 


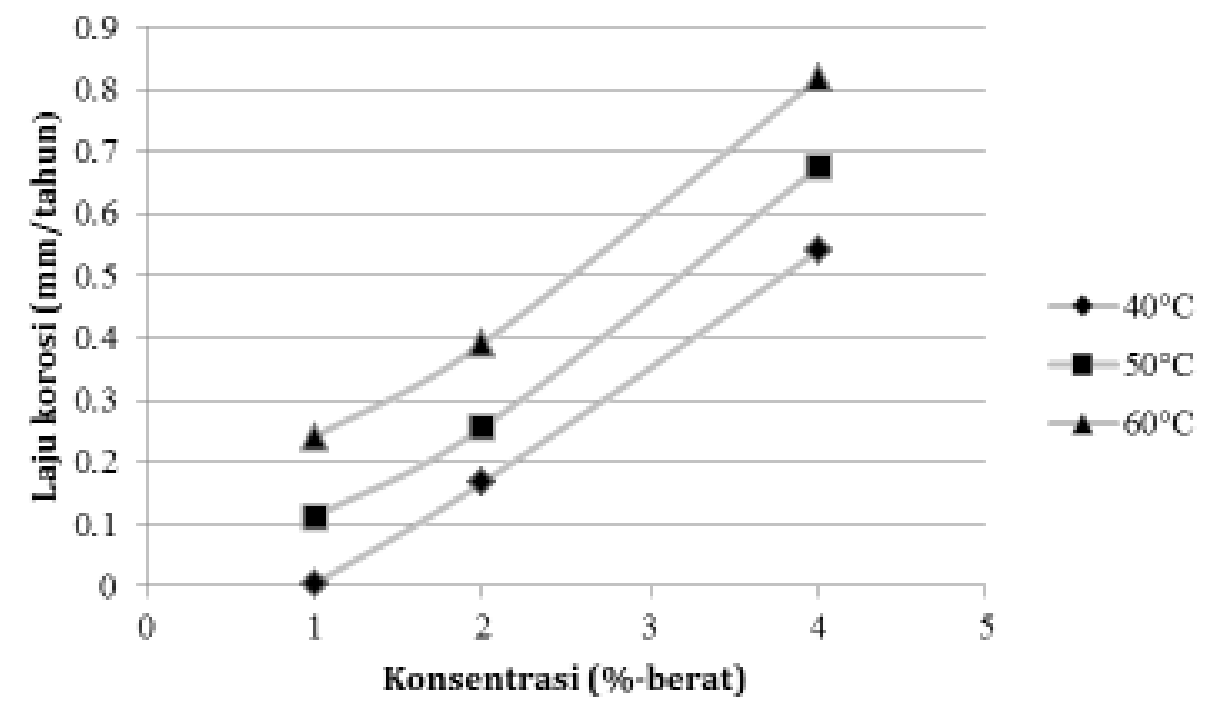

Gambar 5. Laju korosi aluminium terhadap konsentrasi asam sitrat pada berbagai temperatur

Laju korosi yang dipengaruhi oleh konsentrasi asam sitrat $C_{c a}$, dapat dituliskan sebagai:

$r=k \cdot C_{c a}^{n}$

di mana $k$ adalah konstanta laju reaksi, $n$ adalah orde reaksi, dan $C_{c a}$ dalam \%-berat. Dengan menggunakan metode diferensiasi dari pengaluran nilai ln $r$ terhadap $\ln C_{c a}$, regresi linier menghasilkan konstanta nilai $k$ dan $n$ untuk tiap temperatur, seperti ditampilkan pada Tabel 2 .

Tabel 2. Nilai $\boldsymbol{k}$ dan $\boldsymbol{n}$ pada Berbagai Temperatur

\begin{tabular}{cccc}
\hline $\begin{array}{c}\text { Temperatur } \\
\left({ }^{\circ} \mathbf{C}\right)\end{array}$ & $\begin{array}{c}\text { Konstanta } \boldsymbol{k} \\
\text { (mm/tahun) }\end{array}$ & $\begin{array}{c}\text { Orde } \\
\text { reaksi } \\
\boldsymbol{n}\end{array}$ & $\boldsymbol{R}^{\mathbf{2}}$ \\
\hline $\mathbf{4 0}$ & 0,052 & 1,693 & 0,9999 \\
$\mathbf{5 0}$ & 0,109 & 1,296 & 0,9979 \\
$\mathbf{6 0}$ & 0,231 & 0,880 & 0,9858 \\
\hline
\end{tabular}

Dari Tabel 2, nilai $R^{2}$ yang diperoleh dari regresi linier bernilai $>0,98$ sehingga nilai $k$ dan $n$ cukup akurat. Terlihat bahwa temperatur yang lebih tinggi mengakibatkan peningkatan nilai $k$ dan penurunan orde reaksi $n$. Regresi linier dari pengaluran nilai $n$ terhadap $T$ menghasilkan persamaan empiris:

$n=-0,0407 \cdot T+14,428$

dengan $R^{2}$ sebesar 0,9998 .

Mengingat bahwa asam sitrat adalah asam lemah tripotik dengan harga $\mathrm{p} K_{a}$ yang tidak sama untuk setiap tahap ionisasi, derajat ionisasi asam sitrat diduga dapat mengalami perubahan pada temperatur yang berbeda. Dari hasil pengukuran, terbukti bahwa kenaikan konsentrasi asam sitrat dan temperatur dapat menurunkan $\mathrm{pH}$ larutan, seperti ditampilkan pada Tabel 3.

\section{Tabel 3. Derajat Keasamaan (pH) Larutan Asam Sitrat pada Berbagai Temperatur dan Konsentrasi Asam Sitrat.

\begin{tabular}{ccccc}
\hline & \multicolumn{4}{c}{ Temperatur $\left({ }^{\circ} \mathbf{C}\right)$} \\
& & $\mathbf{4 0}$ & $\mathbf{5 0}$ & $\mathbf{6 0}$ \\
\hline \multirow{2}{*}{ Konsentrasi } & $\mathbf{1}$ & 2,3 & 2,0 & 1,8 \\
(\%-b) & $\mathbf{2}$ & 2,1 & 1,8 & 1,6 \\
& $\mathbf{4}$ & 1,9 & 1,6 & 1,4 \\
\hline
\end{tabular}

Dengan demikian, persamaan 4 juga dapat dituliskan menjadi:

$r=k^{\prime} \cdot C_{H}^{n^{\prime}}$

di $C_{H}$ adalah konsentrasi ion $\mathrm{H}^{+}$dalam mol/liter. Dengan menggunakan metode diferensiasi dari pengaluran nilai ln $r$ terhadap $\ln C_{H}$, regresi linier menghasilkan konstanta nilai $k^{\prime}$ dan $n^{\prime}$ untuk tiap temperatur, seperti ditampilkan pada Tabel 4 .

Tabel 4. Nilai $k^{\prime}$ dan $n^{\prime}$ pada Berbagai Temperatur

\begin{tabular}{cccc}
\hline $\boldsymbol{T}\left({ }^{\circ} \mathbf{C}\right)$ & $\boldsymbol{k}^{\prime}(\mathbf{m m} /$ tahun $)$ & $\boldsymbol{n}^{\prime}$ & $\boldsymbol{R}^{\mathbf{2}}$ \\
\hline $\mathbf{4 0}$ & 37583,7 & 2,549 & 0,9999 \\
$\mathbf{5 0}$ & 871,6 & 1,951 & 0,9979 \\
$\mathbf{6 0}$ & 56,1 & 1,325 & 0,9858 \\
\hline
\end{tabular}


Tabel 4 memperlihatkan pula bahwa temperatur yang lebih tinggi mengakibatkan peningkatan nilai $k^{\prime}$ dan penurunan orde reaksi $n^{\prime}$. Regresi linier dari pengaluran nilai $n^{\prime}$ terhadap $T$ menghasilkan persamaan empiris:

$n^{\prime}=-0,0612 \cdot T+21,716$

dengan $R^{2}$ sebesar 0,9998 .

Persamaan 5 dan 7 menunjukkan bahwa kinetika reaksi korosi aluminium oleh asam sitrat tidak dapat dirumuskan secara sederhana dengan power law equation karena persamaan tersebut menghasilkan nilai orde reaksi yang berubah terhadap temperatur. Selain itu, Gambar 4 memperlihatkan bahwa kenaikan temperatur dapat meningkatkan laju korosi. Pada berbagai konsentrasi asam sitrat, terlihat bahwa kenaikan laju korosi dapat dilinierkan.

Pada temperatur yang lebih tinggi, reaksi korosi mendapatkan lebih banyak energi ke dalam sistem dan meningkatkan laju korosi dengan membuat frekuensi tumbukan antarpartikel menjadi makin cepat. Dengan demikian, temperatur yang makin tinggi mempermudah logam untuk melepaskan elektron yang dimilikinya.

Karena laju korosi bergantung terhadap temperatur $T$, konstanta laju reaksi $k$ direpresentasikan dengan hukum Arrhenius:

$k=k_{0} \exp \left(\frac{-E_{a}}{R T}\right)$

di mana $k_{0}$ merupakan faktor frekuensi dan $E_{a}$ adalah energi aktivasi reaksi korosi. Regresi linier dari pengaluran nilai ln $k$ terhadap $1 / T$ menghasilkan nilai $k_{0}$ sebesar $3,57 \times 10^{-9}$ $\mathrm{mm} /$ tahun dan nilai $E_{a}$ sebesar $65,01 \mathrm{~kJ} / \mathrm{mol}$, dengan $R^{2}$ sebesar 0,9997 .

\subsubsection{Pengaruh Interaksi Temperatur dan Konsentrasi Asam Sitrat}

Secara keseluruhan, Persamaan 4 dan 8 menjelaskan bahwa temperatur dan konsentrasi asam sitrat mempengaruhi laju korosi aluminium. Dengan demikian, hasil analisis matematik dari penelitian ini menghasilkan power law equation (PLE) sebagai persamaan laju korosi aluminium dalam larutan asam sitrat, yakni:

$r=\left[3,576 \times 10^{-9} \exp \left(\frac{-65008}{8,314 \cdot T}\right)\right] C_{c a}^{n}$

di mana $r$ dalam $\mathrm{mm} /$ tahun, $T$ dalam Kelvin, $C_{c a}$ dalam \%-berat, dan nilai $n$ terhitung dari Persamaan 5.

$$
\text { Analisis }
$$

varians

(ANOVA) menghasilkan fitted equation (FE) sebagai persaman laju korosi aluminium agar memenuhi data-data pada Tabel 1, yakni:

$$
\begin{aligned}
& r=9,55-0,07 T-0,30 \zeta+1,26 \times 10^{-4} T^{2} \\
& +0,13 \zeta^{2}+9,92 \times 10^{-4} T \zeta
\end{aligned}
$$

di mana $r$ dalam mm/tahun, $T$ dalam Kelvin, $\zeta$ $\equiv{ }^{2} \log C_{c a}$, dan $C_{c a}$ dalam \%-berat, dengan $R^{2}$ sebesar 0,9911 . Nilai $R^{2}$ tersebut menyatakan bahwa persamaan tersebut dapat memberikan hasil prediksi yang sangat baik terhadap laju korosi aluminium dalam larutan asam sitrat. Persamaan 10 bersifat empirik, serta berlaku pada rentang temperatur 40 $60^{\circ} \mathrm{C}$ dan konsentrasi asam sitrat 1-4 \%-b. Data-data hasil percobaan kemudian dibandingkan dengan model dari Persamaan 9 dan 10, seperti ditampilkan pada Gambar 6.

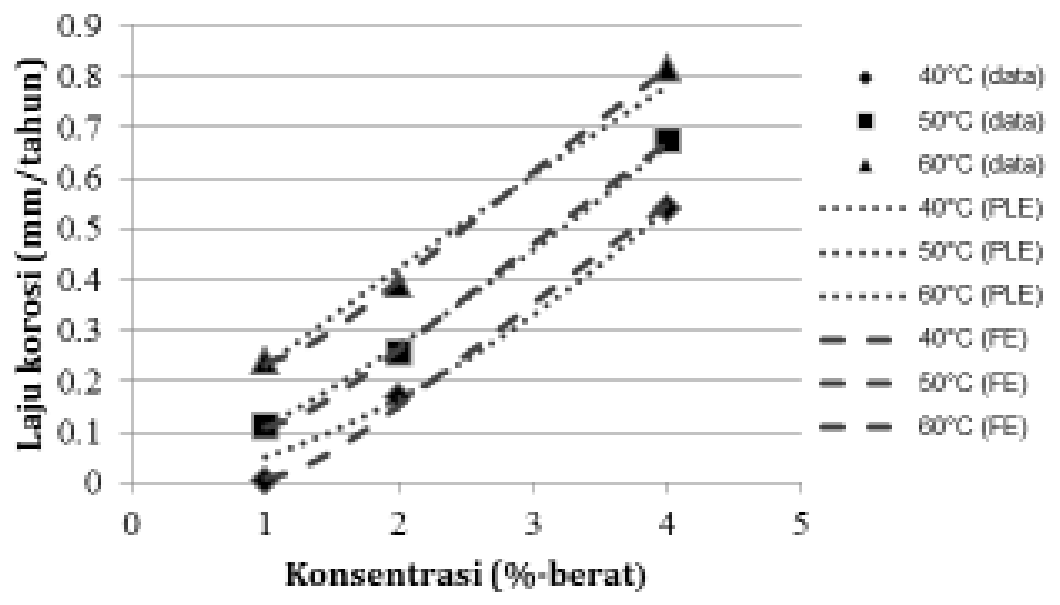

Gambar 6. Perbandingan antara data dengan model laju korosi aluminium terhadap konsentrasi asam sitrat pada berbagai temperatur 


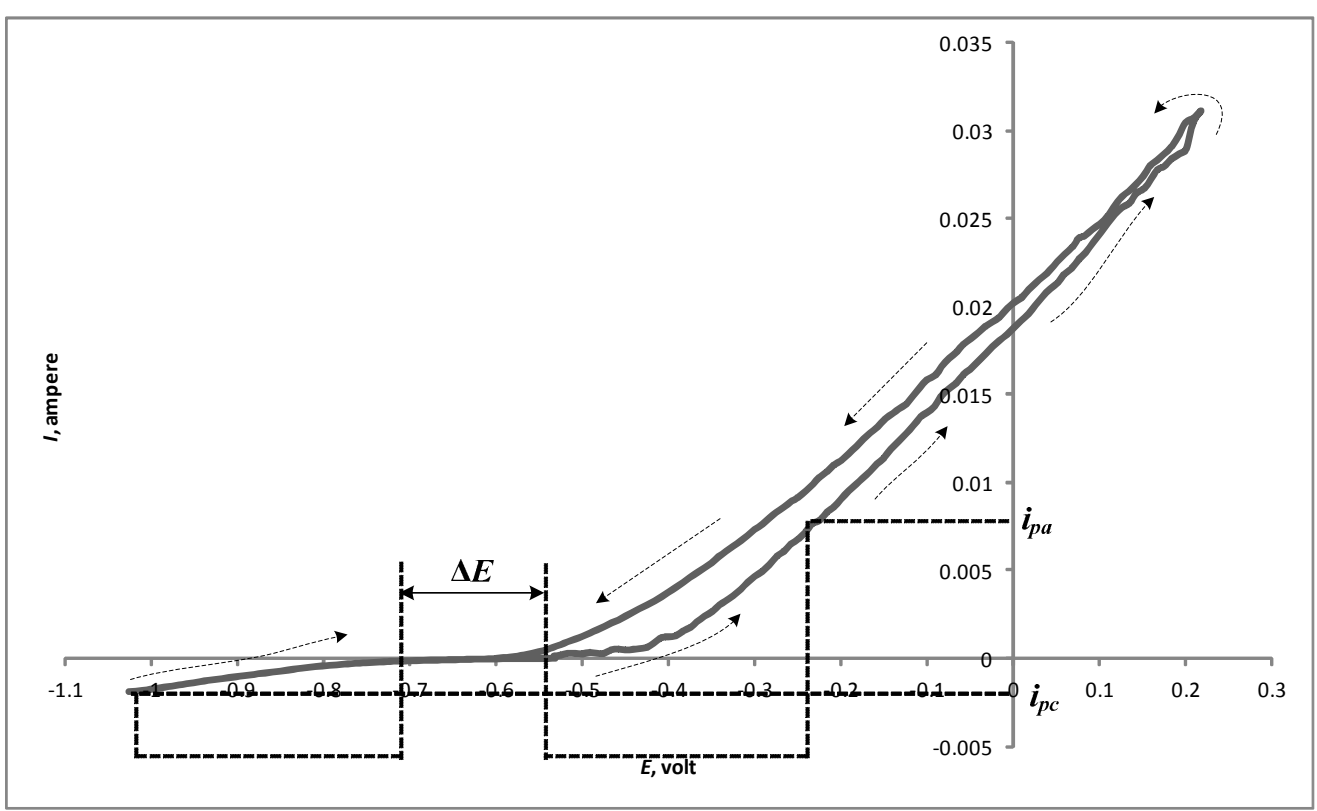

Gambar 7. Voltamogram korosi aluminium dalam larutan asam sitrat 4\%-b pada temperatur $60^{\circ} \mathrm{C}$

Gambar tersebut menunjukkan bahwa model PLE dan FE dapat mewakili sebagian besar data hasil percobaan

\subsection{Mekanisme Korosi}

Metode voltametri siklik digunakan untuk memperoleh informasi mengenai reversibilitas reaksi, kestabilan produk korosi, dan jumlah tahap reaksi oksidasi maupun reduksi. Pada reaksi korosi aluminium dalam larutan asam sitrat, reaksi dianggap reversibel jika $E_{p a}-E_{p c} \leq 0,118 / n \approx$ 0,039 volt. Kestabilan produk korosi diketahui dari rasio antara arus puncak anodik $i_{p a}$ dengan arus puncak katodik $i_{p c}$. Produk korosi yang terbentuk bersifat stabil jika nilai $i_{p a} / i_{p c} \approx 1$. Selain itu, jumlah tahap reaksi diketahui dari jumlah puncak anodik maupun katodik.

Nilai $E_{p a}-E_{p c}$ dan $i_{p a} / i_{p c}$ dalam penelitian diperoleh dari voltamogram dengan forward scan rate $1,67 \mathrm{mV} /$ detik; reverse scan rate 1,67 mV/detik; apex I 1000 $\mathrm{mA} / \mathrm{cm}^{2}$; dan sample period 5 detik. Salah satu voltamogram korosi aluminium dalam larutan asam sitrat ditampilkan pada Gambar 7 .

Dalam percobaan yang dilakukan, rentang potensial kerja yang digunakan tidak mencapai puncak kurva anodik maupun kurva katodik. Oleh karena itu, pendekatan dilakukan untuk mendapatkan rasio arus puncak dan jarak antara potensial puncak yang dapat mewakilkan parameter tersebut. Potensial puncak diamati dengan mengukur titik awal saat kedua kurva naik. Selisih potensial antara titik awal saat kedua kurva naik dianggap sudah mewakili jarak kedua potensial puncak tersebut. Rasio arus puncak didekati dengan besar arus yang dihasilkan pada jarak potensial yang sama dari titik saat masing-masing kurva mulai naik. Hasil penelitian terhadap mekanisme korosi aluminium dalam larutan asam sitrat disajikan pada Tabel 5.

Tabel 5 menunjukkan bahwa semua nilai $i_{p a} / i_{p c} \neq 1$, yang memperlihatkan bahwa produk korosi aluminium dalam larutan asam sitrat tidak bersifat stabil. Hasil analisis difraksi sinar-X pada produk korosi aluminium tidak mendeteksi adanya senyawa aluminium kristalin. Dengan demikian, kation $\mathrm{Al}^{3+}$ hasil reaksi korosi berikatan dengan anion yang ada di dalam larutan membentuk garam aluminium amorf yang tidak mudah tereduksi kembali menjadi logam Al. Selain itu, Tabel 6 juga menunjukkan bahwa semua nilai $\Delta E>0,039$ volt, sehingga reaksi oksidasi aluminium oleh larutan asam sitrat merupakan reaksi irreversibel.

Tabel 5. Hasil Pengukuran $E_{p a}-E_{p c}$ dan $i_{p a} / i_{p c}$ dari Voltametri Siklik

\begin{tabular}{cccc}
\hline $\boldsymbol{C}_{\boldsymbol{c a}}(\boldsymbol{\%}$-b) & $\boldsymbol{T}\left({ }^{\circ} \mathbf{C}\right)$ & $\boldsymbol{\Delta E}$ (volt) & $\boldsymbol{i}_{\boldsymbol{p a}} / \boldsymbol{i}_{\boldsymbol{p c}}$ \\
\hline $\mathbf{1}$ & $\mathbf{4 0}$ & 0,193 & 4,125 \\
$\mathbf{1}$ & $\mathbf{6 0}$ & 0,192 & 5,324 \\
$\mathbf{4}$ & $\mathbf{6 0}$ & 0,181 & 4,366 \\
\hline
\end{tabular}


Kurva voltamogram pada Gambar 7 menunjukkan bahwa kurva anodik memiliki satu puncak. Dengan demikian, aluminium terkorosi dalam larutan asam sitrat dengan satu tahap. Pelepasan elektron pada aluminium menjadi ion $\mathrm{Al}^{3+}$ terjadi secara simultan tanpa melalui pembentukan $\mathrm{Al}^{+}$dan $\mathrm{Al}^{2+}$ terlebih dahulu. Oleh karena itu, terbukti bahwa Persamaan 1 menjelaskan reaksi elementer yang terjadi pada permukaan anoda.

Selain itu, terlihat pula bahwa arus anodik pada reverse scan lebih besar dari arus anodik pada forward scan. Hal ini menjelaskan bahwa laju reaksi anodik balik lebih besar dari laju reaksi anodik maju karena luas permukaan anoda menjadi lebih besar akibat terkorosi.

\section{Kesimpulan}

Berdasarkan penelitian yang telah dilakukan, dapat diambil kesimpulan bahwa aluminium terkorosi dalam larutan asam sitrat menjadi $\mathrm{Al}^{3+}$ dengan satu tahap reaksi searah. Produknya bersifat tidak stabil, langsung membentuk garam aluminium amorf. Laju korosi aluminium meningkat seiring dengan peningkatan temperatur dan konsentrasi asam sitrat, seperti dijelaskan secara matematik pada power law equation (PLE) dengan Persamaan 9, maupun pada fitted equation (FE) dengan Persamaan 10.

Energi aktivasi korosi aluminium di dalam larutan asam sitrat bernilai 65,01 $\mathrm{kJ} / \mathrm{mol}$. Dalam rentang konsentrasi 1-4 \%berat dan temperatur $40-60^{\circ} \mathrm{C}$, laju korosi aluminium dapat digolongkan pada laju korosi "dapat diabaikan" (kurang dari 2 mpy) hingga "sedang" (20-50 mpy).

\section{Daftar Pustaka}

Bard, J. A.; Faulkner, L. R., Électrochimie Principes, Méthods et Applications, Masson, Paris, 1983; hal. 239-270.

Brown, H.; James, W., Packaged Product Quality And Shelf Life, dalam Food Packaging Technology, Bab 3, Coles, R.; McDowell, D.; Kirwan, M. J., Editor, Copenhagen, 2003; hal. 65-1.

Fontana, M. G.; Corrosion Engineering, $3^{\text {rd }}$ Edition, McGraw-Hill International, Ohio, 1987; hal. 23-28.

Jones, D. A.; Principles and Prevention of Corrosion, Macmillan Publishing Company, New York, 1992; hal. 9-124.

National Associaton of Corrosion Engineers; Corrosion Data Survey, Metals Section, Sixth Edition, An Official NACE Publication, Texas, 1985; hal. 40-41.

Robertson, G. L.; Food Packaging: Principles and Practice, Marcel Dekker, New York, 1993; hal. 182-184, 338-363.

Winata, A. R.; Mardianto, F.; Korosivitas Larutan Asam Sitrat, Tugas Akhir Program Sarjana: Institut Teknologi Bandung, Juli 2010; hal. 27-43. 